\title{
Endothelin-1 mRNA Is Widely Expressed in Porcine and Human Tissues
}

Derek J. R. Nunez, Morris J. Brown, Anthony P. Davenport, Craig B. Neylon, ${ }^{\star}$ J. Paul Schofield, ${ }^{\star}$ and Richard K. Wyse ${ }^{\mathbf{5}}$ Clinical Pharmacology Unit, Level 2, F \& G Block, Addenbrooke's Hospital, Cambridge CB2 2QQ, United Kingdom; *Department of Biochemistry, Institute of Animal Physiology and Genetics Research, Babraham, Cambs CB2 4AT, United Kingdom;

${ }^{\ddagger}$ Medical Research Council, Molecular Genetics Unit, Department of Medicine, University of Cambridge, Addenbrooke's Hospital, Cambridge CB2 2QQ, United Kingdom; and ${ }^{\S}$ Department of Paediatric Cardiology, Hospital for Sick Children, London WC1, United Kingdom

\begin{abstract}
Endothelin-1 (ET-1) is a potent vasoconstrictor peptide isolated from porcine endothelial cells. We have previously demonstrated widespread binding sites for ET-1 in blood vessels, heart, kidney, adrenal, lung, and brain in a distribution that paralleled that of endothelial cells. To determine whether these cells are capable of synthesizing ET-1 in close proximity to its binding sites, amplification of cDNA using the polymerase chain reaction and in situ hybridization were used to study the distribution of ET-1 mRNA. We have found widespread transcription of ET-1 mRNA in human and porcine tissues. The identity of the transcripts was confirmed by prediction of restriction fragment lengths or sequencing. In situ hybridization in the kidney showed that the regional expression of these transcripts is localized, probably to small blood vessels, but the failure to visualize ET-1 mRNA in the capillaries may reflect absence of expression or insufficient sensitivity of the technique. These results should permit investigation of the role of ET-1 as a local factor in vascular pathophysiology. ( $J$. Clin. Invest. 1990. 85:1537-1541.) endothelin • expression • mRNA - PCR • in situ hybridization
\end{abstract}

\section{Introduction}

Endothelin-1 (ET-1) ${ }^{1}$ is a potent 21 -amino acid vasoconstrictor peptide with mitogenic properties isolated from supernatants of cultured pig aortic endothelial cells (1-3). In the original report by Yanagisawa and colleagues (1), ET-1 mRNA was detectable by Northern analysis only in aortic endothelial cells, but not in kidney, adrenal, right atrium, lung, or brain. This appeared surprising as ET-1 might be expected to have its principal role as a locally released factor in small blood vessels which are of much greater importance for the regulation of vascular resistance than the aorta. We have recently reported binding sites for ET-1 in each of the above tissues in a distri-

Address reprint requests to Dr. Nunez, Clinical Pharmacology Unit, F\&G Block, Level 2, Addenbrooke's Hospital, Hills Rd., Cambridge CB2 2QQ, United Kingdom.

Received for publication 24 August 1989 and in revised form 15 November 1989.

1. Abbreviations used in this paper: ET-1, endothelin-1; HEC, human umbilical vein endothelial cells; $L V$, left ventricle; PAo, pig aortic endothelial scrapings; PCR, polymerase chain reaction; RV, right ventricle.

J. Clin. Invest.

(c) The American Society for Clinical Investigation, Inc

0021-9738/90/05/1537/05 \$2.00

Volume 85, May 1990, 1537-1541 bution paralleling that of endothelial cells stained with an anti-Von Willebrand Factor antibody $(4,5)$. Therefore, we examined whether ET-1 mRNA is synthesized by endothelial cells in these tissues from pig and man and whether endothelial cells differ in their capacity to synthesize ET-1 mRNA. Two techniques more sensitive than Northern analysis were employed. The principal method used has been the combination of reverse transcription of extracted RNA and subsequent enzymatic amplification by the powerful polymerase chain reaction (PCR) technique of the cDNA thus formed (6). In the kidney, we have sought to localize ET-1 mRNA by in situ hybridization (7) in order to exclude 'illegal transcription' (8, 9) as a source of positive cDNA amplification results.

\section{Methods}

Total RNA was isolated by a modified guanidinium isothiocyanate method (10) from: $(a)$ pig aortic endothelial cell scrapings, $(b)$ pig heart (left atrium; right atrium; left ventricle [LV]; and right ventricle [RV]), adrenals, and kidney (cortex, medulla), (c) human umbilical vein endothelial cells (HEC) cultured as described previously (11), and $(d)$ human cardiac chambers (LV, RV) and lung from a 16-yr-old male who received a heart-lung transplant for cystic fibrosis. cDNA was generated using $10 \mu \mathrm{g}$ (HEC and aortic endothelial scrapings) or $60 \mu \mathrm{g}$ (other tissues) of total RNA as template by incubating for $2 \mathrm{~h}$ at $37^{\circ} \mathrm{C}$ $20 \mu \mathrm{l}$ reactions containing reverse transcription buffer $(50 \mathrm{mM}$ Tris$\mathrm{HCl} \mathrm{pH} 8.3,10 \mathrm{mM} \mathrm{MgCl}, 75 \mathrm{mM} \mathrm{KCl}, 10 \mathrm{mM}$ dithiothreitol), deoxynucleotides ( $2.5 \mathrm{mM}$ each), 10 pmol of a specific ET-1 antisense primer (pig primer: 5'-GTT ATG GGT CAC TTT CTT ATC TCT GTA GAG CTC GGC; human primer: 5'-GGT CAC ATA ACG CTC TCT GGA GGG CTT), or oligo-dT 15 (BCL), $120 \mathrm{U}_{\text {human placental }}$ ribonuclease inhibitor (Pharmacia Fine Chemicals, Piscataway, NJ), 4 $\mu \mathrm{g}$ nuclease-free BSA (BCL) and $30 \mathrm{U}$ cloned murine Maloney leukaemia virus reverse transcriptase (Pharmacia Fine Chemicals). The products were diluted to $100 \mu \mathrm{l}$ with $10 \mathrm{mM}$ Tris- $\mathrm{HCl} \mathrm{pH} \mathrm{8.0,1} \mathrm{mM}$ EDTA and heated to $93^{\circ} \mathrm{C}$ for $3 \mathrm{~min}$. Then $5 \mu \mathrm{l}$ of the diluted cDNA were amplified using two specific ET-1 primers (common forward primer: 5'-TGC TCC TGC TCT TCC CTG ATG GAT AAA GAG TGT GTC; backward primers as for reverse transcription) at a concentration of $1 \mu \mathrm{M}$ and $3 \mathrm{U}$ of cloned Taq polymerase (Amplitaq; Perkin-Elmer Cetus, Emeryville, $\mathrm{CA})$ as recommended by the enzyme supplier. PCR was performed for 60 cycles $\left(93^{\circ} \mathrm{C}\right.$ for $1 \mathrm{~min}, 60^{\circ} \mathrm{C}$ for $3.5 \mathrm{~min}$; final extension $60^{\circ} \mathrm{C}$ for $30 \mathrm{~min}$ ). The PCR products were separated by agarose gel electrophoresis, blotted onto Hybond $\mathrm{N}$ membrane (Amersham Corp., Arlington Heights, IL), and probed with $\mathrm{a}^{35} \mathrm{~S} 5^{\prime}$ end-labeled 21-mer oligonucleotide (5'-CCA GAT GAT GTC CAG GTG GCA) specific for an ET-1 cDNA sequence occurring between the two primers used in the PCR. After stringent washing (down to $20 \mathrm{mM} \mathrm{Na}^{+}$at $37^{\circ} \mathrm{C}$ ), the blots were dried and exposed to autoradiography film. Control RNAs were pretreated with RNase-free DNase (Pharmacia Fine Chemicals, $3 \mathrm{U}, 30 \mathrm{~min}$ at $37^{\circ} \mathrm{C}$ ) before cDNA synthesis and PCR. The amplified products were subjected to restriction fragment length analysis using the enzymes Pvu II and Hind III (BCL and Amersham International, Amersham, UK, respectively) 

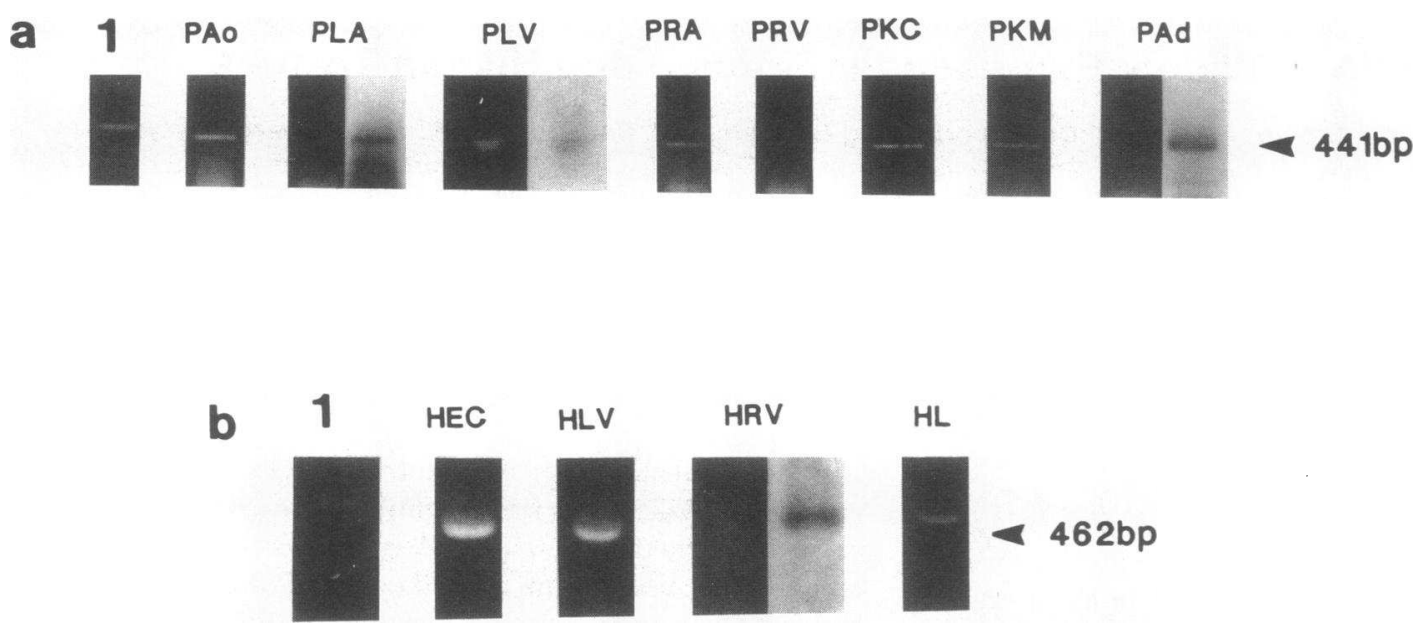

Figure 1. Amplification of ET-1 cDNA from pig and human tissues. The products of PCR amplification of cDNA were separated by agarose gel electrophoresis and visualized with ethidium bromide. The specific 441- (pig) and 462-bp (human) bands derived from ET-1 cDNA are shown in $a$ and $b$, respectively. In the samples from pig LA and adrenal and human RV, the bands are not clearly seen, but are detected by Southern hybridization with the 21-mer ${ }^{35}$ S-labeled probe (arrows). Samples from pig tissues: PAo: aortic endothelial cell scrapings; PLA: left atrium; PLV: left ventricle; PRA: right atrium; PRV: right ventricle; PAd: adrenal; PKC: kidney cortex; PKM: kidney medulla. Human cDNA samples: HLV: left ventricle; HRV: right ventricle; HL: lung. The lanes marked $l$ are a portion of a 1-kb DNA ladder (Bethesda Research Laboratories, Gaithersburg, MD) (size markers: 506, 396, 344, and 298 bp).

under the conditions recommended by the supplier. Confirmation that these controls ensured specificity was sought by sequencing of the human PCR-amplified bands of cDNA. Direct sequencing was per- formed by a modification of the dideoxy chain termination procedure, in which Taq polymerase was substituted for Sequenase (12).

In order to determine whether ET-1 transcription is localized
PKM

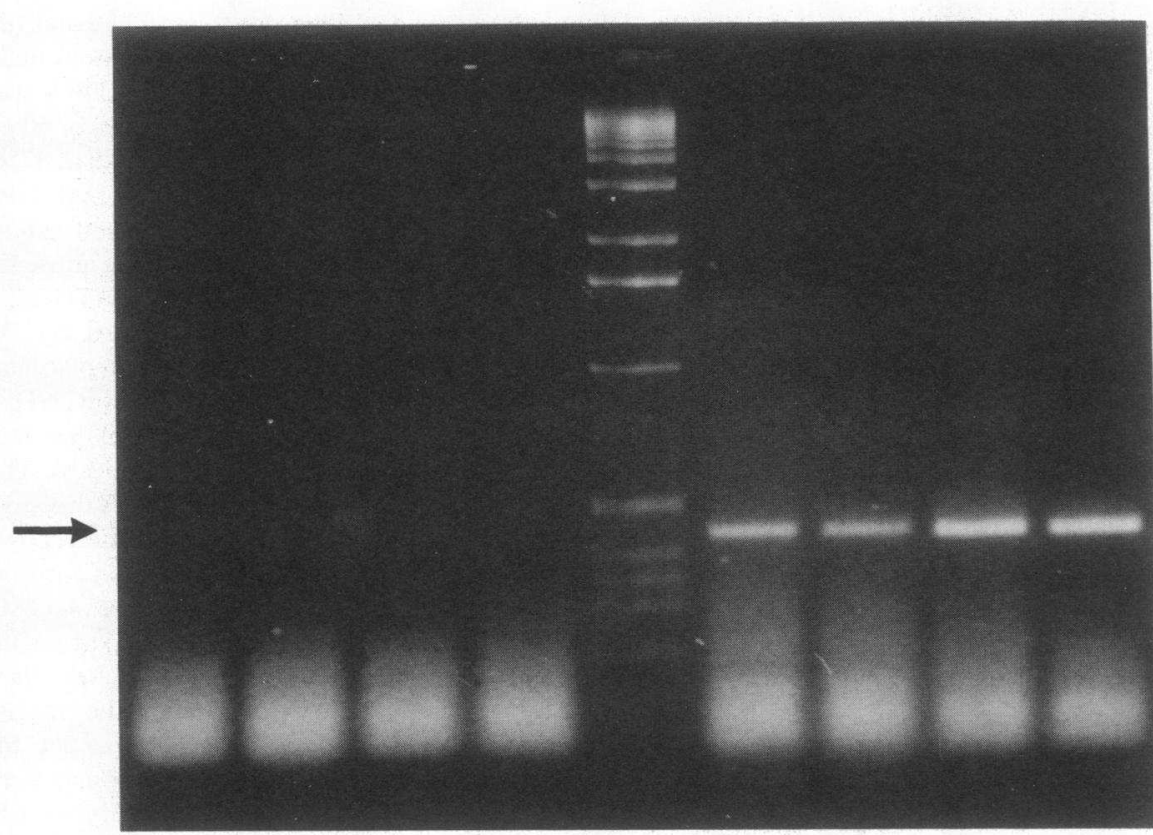

DNase

RT
PAO

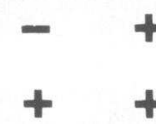

PAO

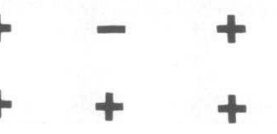

HLV
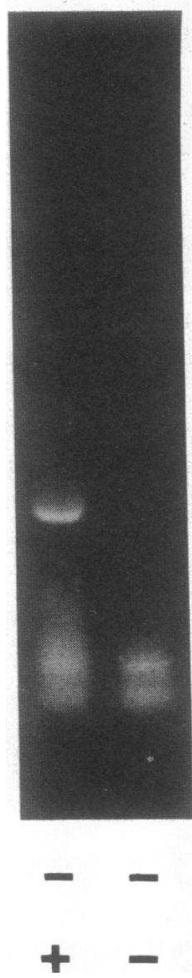

Figure 2. Effect of reverse transcription and pretreatment with DNase on ET-1 cDNA amplification. PCR products from pig aortic endothelial cell and renal medulla cDNA and human left ventricular CDNA were separated by electrophoresis. Control RNA samples were pretreated with RNase-free DNase before reverse transcription and PCR. The presence of the specific ET-1 amplification band (arrow) depends on the use of reverse transcriptase, but is independent of pretreatment with DNase. PKM: Pig kidney medulla; HLV: human left ventricle. The 1-kb ladder (Bethesda Research Laboratories) is included for size comparison. 


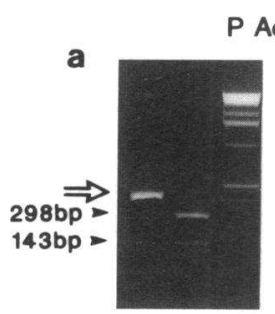

c Hilndill
P Ao

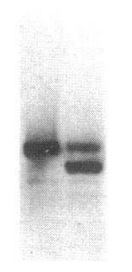

C HinduI

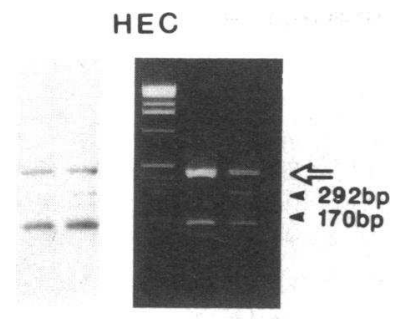

c Hindill c Hindu

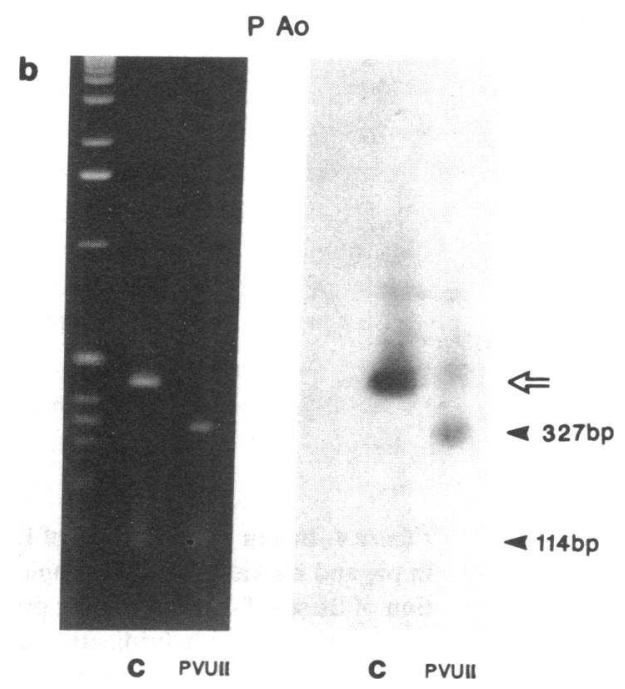

C PVuII within a tissue, in situ hybridization was performed as previously described (7). Briefly, $10 \mu \mathrm{m}$ frozen sections of pig and rat kidney were thaw-mounted and dried onto gelatin-coated slides. The sections were fixed in $4 \%$ formaldehyde solution in $50 \mathrm{mM}$ phosphate buffered saline (pH 7.5) and hybridized with a $36-\mathrm{mer}^{35} \mathrm{~S} 5^{\prime}$ end-labeled antisense oligodeoxynucleotide probe complementary to the mRNA coding for ET-1 ${ }_{1-12}$ (5'-GAC ACA CTC TTT ATC CAT CAG GGA AGA GCA GGA GCA). As a negative control, adjacent sections were hybridized with a $36-$ mer ${ }^{35} \mathrm{~S} 5$ '-labeled sense probe identical to the mRNA coding sequence for $\mathrm{ET}-1_{1-12}$.

\section{Results}

Amplification of cDNA with the PCR demonstrated ET-1 mRNA in all tissues examined (Fig. 1). After electrophoretic separation, an amplification band of the predicted size ( $441 \mathrm{bp}$ for pig; 462 bp for human) was seen in all the samples studied by autoradiography after Southern blotting and hybridization with a $21-\mathrm{mer}^{35} \mathrm{~S}$-labeled oligonucleotide complementary to a sequence within the cDNA between the primers, although in some cases (e.g., pig adrenal and human RV) it was not visible by ethidium fluorescence. Fig. 2 shows that the presence of this predicted amplification band in pig kidney medulla and aortic cell RNA and in human LV RNA samples is dependent on the use of reverse transcriptase, but is not affected by pretreatment with DNase. The specificity of the amplification band was also confirmed by: (a) analysis of restriction fragment sizes obtained from the PCR products after cleavage with Hind III and Pvu II (Fig. 3), and (b) direct sequencing of the human amplification band which showed that this was identical with the published cDNA sequence (13).

Having established with reverse transcription PCR that the kidney contains ET-1 mRNA, we used in situ hybridization to
Figure 3. Restriction enzyme digestion of the ET-1 amplification band. The PCR products were digested with the restriction enzymes Hind III ( $a$ ) and Pvu II (b). Agarose gel electrophoresis and Southern hybridization with the 21 -mer ${ }^{35} \mathrm{~S}$-labeled probe reveal that the 441-bp band derived from the pig samples is cleaved by both enzymes at the positions predicted from the cDNA sequence between the PCR primers (Hind III, 298 and 143 bp; Pvu II, 327 and $114 \mathrm{bp}$ ). The human cDNA does not contain a restriction site for Pvu II, but Hind III produces the expected cleavage products (292 and $170 \mathrm{bp).} \mathrm{Open} \mathrm{arrows,} \mathrm{parent} \mathrm{bands;} \mathrm{arrowheads,} \mathrm{cleav-}$ age products of the sizes indicated; $c$, control undigested sample.

study its localization in this organ since the kidney contains an anatomically well-defined branching network of blood vessels, and the glomeruli are also an obvious concentrate of endothelial cells (5). In sections of pig kidney, in situ hybridization using a 36-mer ${ }^{35}$ S-labeled ET-1 antisense oligonucleotide and macroautoradiography demonstrates that probe hybridization is discretely localized (Fig. $4 a$ ). Adjacent control sections hybridized with a labeled sense probe did not show any discrete areas of binding (results not shown). As we had previously shown that ET-1 binding sites were absent in pig and human glomeruli, but were distributed differently in the rat (5), we also localized ET-1 mRNA in the latter species. In the rat, the pattern of hybridization was similar to that in the pig (Fig. $4 b$ ). Inasmuch as the whole organ can in this case be visualized on the slide, the distribution of hybridization appears consistent with probe-binding to arcuate and interlobular-sized vessels.

\section{Discussion}

These results demonstrate the expression of ET-1 mRNA in porcine aortic endothelial cells, all heart chambers, adrenals, and kidney (cortex and medulla), as well as in human cardiac ventricular tissue, lung, and cultured umbilical endothelial cells.

We have validated the source of the PCR bands to exclude spurious genomic DNA amplification. The minimum criterion, applied in each case, was the demonstration of a requirement for initial reverse transcription before PCR. The full confirmation, applied to the amplified ET-1 cDNA from the human samples, was to sequence these and demonstrate lack of an intronic inclusion that would be present in genomic DNA. When the above studies were first devised, only very 

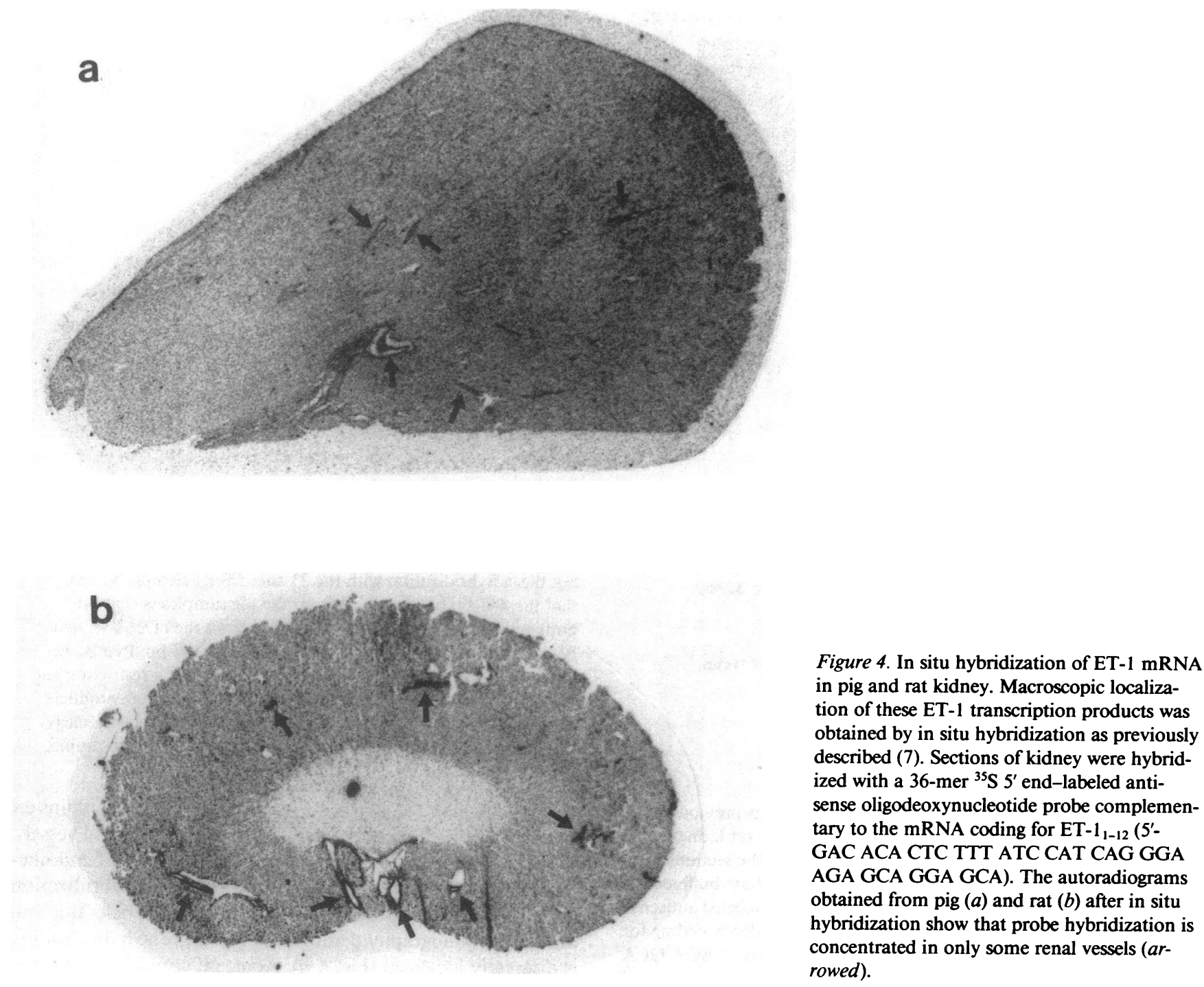

limited data on the sequence of the endothelin gene were available (14); our PCR primers were designed to span an intron, but its full size was unknown. Bloch and colleagues (15) have now published the sequence of the human ET-1 gene which shows that in the human genome the length of the intronic DNA between the primers is at least several thousand base pairs.

The previous negative report using Northern analysis and the degree of amplification required in the present study to detect the cDNA from ET-1 mRNA suggest that transcript prevalence is low. In applications of PCR to the study of genomic DNA, extreme care is necessary to avoid contamination. As explained above, the application of the technique to cDNA avoids much of the problem, because a positive requires mRNA to be present in the original sample, and the chance of contamination with 'stray' RNA, which is not itself amplified, should be negligible (considerably less than the chance of losing RNA through ubiquitous RNase activity). Having found widespread mRNA expression of ET-1, we were therefore concerned to exclude the possibility of 'illegitimate transcription' in a small proportion of cells $(8,9)$. The in situ hybridization studies in the kidney were intended to determine whether the mRNA transcripts of the ET-1 gene are localized, inasmuch as several copies of mRNA per cell are required for a positive result (7). The predicted site of localization was the blood vessels. The distribution of probe binding reported here is similar to that recently published (16). Confirmation in both cases of the cellular site of expression will require microautoradiographic study, which is hindered by the small size of the radioactive signal.

Endothelin has also now been found in the circulation (17-20). Indeed, the rapid removal of ET-1 from the plasma (21) also argues for the presence of a tonically active synthetic machinery if steady-state plasma levels are to be maintained. The mRNA for ET-1 has itself been shown to have a short half-life of $\sim 15 \mathrm{~min}(22)$, so that the detection of occasional 'illegitimate transcription' would be even less likely than for other mRNA molecules.

cDNA for human ET-1 has been prepared from placenta (11), but here we have presented the first demonstration of widespread ET-1 mRNA expression. Demonstration of mRNA expression does not prove that translation into mature ET-1 peptide necessarily occurs. Yet the technique of reverse transcription PCR with transcript sequencing may be considered a necessary step in proving local synthesis of ET-1 because detection of low levels of immunoreactive ET-1 (23) is less specific and there is no technique for amplifying extracted peptide to the amounts required for confirmation of peptide 
sequence. Furthermore, the pseudoirreversible binding of ET-1 to its binding sites (24-26) will make it difficult to determine whether immunoreactive ET-1 in a tissue was synthesised locally, unless immunoreactivity is restricted to endothelial cells.

The present data and the extensive network of ET-1 binding sites and endothelial cells suggest that ET-1 may exert local vasoactive and mitogenic effects in vivo. This possibility appears important to establishing the pathophysiological roles of ET- 1 because the circulating levels now being reported in health and disease (17-20) are much lower than threshold levels required to cause constriction of isolated blood vessels $(1,4)$. Although microautoradiography will be required to define probe hybridization at the cellular level, the macroautoradiographs suggest that ET-1 mRNA expression is limited to only some presumed vascular sites in a healthy tissue and it will be important to determine whether the pattern is altered in disease.

\section{Acknowledgments}

We thank Drs. W. Reik, A. Weetman, and S. Jones for their help, Mr. M. Elliott for the human tissue samples, and Mrs. J. Bacon for excellent technical support.

This work is supported by the Wellcome Trust. Dr. Nunez is a Squibb Cardiovascular Research Fellow and Dr. Davenport is a British Heart Foundation lecturer.

\section{References}

1. Yanagisawa, M., H. Kurihara, S. Kimura, Y. Tomobe, M. Kobayashi, Y. Mitsui, Y. Yazaki, K. Goto, and T. Masaki. 1988. A novel potent vasoconstrictor peptide produced by vascular endothelial cells. Nature (Lond.). 332:411-415.

2. Hiley, C. R. 1989. Functional studies on endothelin catch up with molecular biology. Trends in Pharmacol. Sci. 10:47-49.

3. Inoue, A., M. Yanagisawa, S. Kimura, Y. Kasuya, T. Miyauchi, K. Goto, and T. Masaki. 1989. The human endothelin family: three structurally and pharmacologically distinct isopeptides predicted by three separate genes. Proc. Natl. Acad. Sci. USA. 86:2863-2867.

4. Davenport, A. P., D. J. Nunez, J. A. Hall, A. J. Kaumann, and M. J. Brown. 1988. Autoradiographical localization of binding sites for porcine $\left[{ }^{125} \mathrm{I}\right]$ endothelin 1 in humans, pigs and rats: functional relevance in humans. J. Cardiovasc. Pharmacol. 13(Suppl. 5):S166-170.

5. Davenport, A. P., D. J. Nunez, and M. J. Brown. 1989. Binding sites for $\left[{ }^{125}\right]$ endothelin 1 in the kidney: Differential distribution in rat, pig and man. Clin. Sci. (Lond.). 77:129-131.

6. Saiki, R. K., D. H. Gelfand, S. Stoffel, S. J. Scharf, R. Higuchi, G. T. Horn, K. B. Mullis, and H. A. Erlich. 1988. Primer-directed enzymatic amplification of DNA with a thermostable DNA polymerase. Science (Wash. DC). 239:487-491.

7. Nunez, D. J., A. P. Davenport, P. C. Emson, and M. J. Brown. 1989. A quantitative 'in-situ' hybridization method using computerassisted image analysis. Validation and measurement of Atrial Natriuretic Factor (ANF) messenger RNA in the rat heart. Biochem. J. 263:121-127.

8. Sarkar, G., and S. Sommer. 1989. Access to a messenger RNA sequence or its protein product is not limited by tissue or species specificity. Science (Wash. DC). 244:331-334.

9. Chelly, J., J.-P. Concordet, J.-C. Kaplan, and A. Kahn. 1989. Illegitimate transcription: transcription of any gene in any cell type. Proc. Natl. Acad. Sci. USA. 86:2617-2621.
10. Chomczynski, P., and N. Sacchi. 1987. Single step method of RNA isolation by guanidinium thiocyanate-phenol-chloroform extraction. Anal. Biochem. 162:156-159.

11. Jaffe, E., R. Nachman, C. Becker, and C. R. Minick. 1973. Culture of human endothelial cells derived from umbilical veins. $J$. Clin. Invest. 52:2745-2756.

12. Winship, P. R. 1989. An improved method for directly sequencing PCR amplified material using dimethyl sulphoxide. Nucleic Acids Res. 17:1266.

13. Itoh, Y., M. Yanagisawa, S. Ohkubo, C. Kimura, T. Kosaka, A Inoue, N. Ishida, Y. Mitsui, H. Onda, M. Fujino, and T. Masaki. 1988. Cloning and sequence analysis of cDNA encoding the precursor of a human endothelium-derived vasoconstrictor peptide, endothelin: identity of human and porcine endothelin. FEBS (Fed. Eur. Biochem. Soc.) Lett. 231:440-444.

14. Yanagisawa, M., A. Inoue, T. Ishikawa, Y. Kasuya, S. Kimura, S.-I. Kumagayi, K. Nakayima, T. Watanabe, S. Sakakibara, K. Goto, and T. Masaki. 1988. Primary structure, synthesis, and biological activity of rat endothelin, an endothelium-derived vasoconstrictor peptide. Proc. Natl. Acad. Sci. USA. 85:6964-6967.

15. Bloch, K. D., S. P. Friedrich, M.-E. Lee, R. L. Eddy, T. B. Shows, and T. Quertermous. 1989. Structural organization and chromosomal assignment of the gene encoding endothelin. J. Biol. Chem. 264:10851-10857.

16. MacCumber, M. W., C. A. Ross, B. M. Glaser, and S. H. Snyder. 1989. Endothelin: visualization of mRNAs by in situ hybridization provides evidence for local action. Proc. Natl. Acad. Sci. USA. 86:7285-7289.

17. Suzuki, N., H. Matsumoto, C. Kitada, H. Matsumoto, C. Kitade, M. Yanagisawa, T. Miyauchi, T. Masaki, and M. Fujino. 1988. Immunoreactive endothelin 1 in plasma detected by a sandwich type enzyme immunoassay. J. Cardiovasc. Pharmacol. (Suppl. 5):S151152.

18. Ando, K., Y. Hirata, M. Shichiri, T. Emori, and F. Marumo. 1989. Presence of immunoreactive endothelin in human plasma. FEBS (Fed. Eur. Biochem. Soc.) Lett. 245:164-166.

19. Hartter, E., and W. Woloszczuk. 1989. Radioimmunoassay of endothelin. Lancet. i:909(L).

20. Koyama, H., T. Tabata, Y. Nishzawa, T. Inoue, H. Morii, and T. Yamaji. 1989. Plasma endothelin levels in patients with uraemia. Lancet. i:991-992.

21. Anggard, E., S. Galton, G. Rae, R. Thomas, L. Mcloughlin, G. de Nucci, and J. Vane. 1988. The fate of radioiodinated endothelin 1 and endothelin 3 in the rat. J. Cardiovasc. Pharmacol. 13(Suppl. 5):S46-49.

22. Yanagisawa, M., A. Inoue, Y. Takuwa, Y. Mitsu, M. Kobayashi, and T. Masaki. 1988. The human preproendothelin-1 gene: possible regulation by endothelial phosphoinositide turnover signaling. $J$. Cardiovasc. Pharmacol. 13(Suppl. 5):S13-17.

23. Kitamura, K., T. Tanaka, J. Kato, T. Eto, and K. Tanaka. 1989. Regional distribution of immunoreactive endothelin in porcine tissue: abundance in inner medulla of kidney. Biochem. Biophys. Res. Commun. 161:348-352.

24. Chabrier, P. E., M. Auguet, P. Roubert, M. O. Louchampt, V. Gillard, J. M. Guillon, S. Delaflotte, and P. Braquet. 1988. Vascular mechanism of action of endothelin-1: effect of $\mathrm{Ca}^{2+}$ antagonists. $J$. Cardiovasc. Pharmacol. 13(Suppl. 5):S32-35.

25. Hirata, Y., H. Yoshimi, S. Takata, T. X. Watanabe, S. Kumagai, K. Nakajima, and S. Sakakibara. 1988. Cellular mechanism of action by a novel vasoconstrictor endothelin in cultured rat vascular smooth muscle cells. Biochem. Biophys. Res. Commun. 154:868-875.

26. Jones, C. R., C. R. Hiley, J. T. Pelton, and M. Mohr. 1989. Autoradiographic visualization of binding sites for [ $\left.{ }^{125} \mathrm{I}\right]$ endothelin in rat and human brain. Neurosci. Lett. 97:276-279. 